- Không gặp tai biến và biến chứng nặng trong và sau mổ, có 01 trường hợp chiếm chảy máu chân Trocart rốn sau mổ phải băng ép không cần khâu lại.

- Nhìn chung phẫu thuật nôi soi: dễ quan sát ổ bụng và vòi trứng bên đối diện phẫu thuật nhẹ nhàng, chính xác, vết mổ nhỏ, thời gian phục hồi nhanh, giảm liều lượng và số lượng kháng sinh, giảm các biến chứng do phẫu thuật và sau mổ, tính thẩm mỹ cao.

\section{TÀI LIÊU THAM KHẢO}

1. Phàm văn Lình (2004), "Giải phẫu và sinh lý của hệ sinh sản nữ", Nội tiết học sinh sản", NXBY học, tr. 166-184.

2. Lế Anh Tuấn (2004). Hút điều hòa kinh nguyệt có biến chứng sớm và hậu quả chửa ngoài tử cung ở 3 bệnh viện Phụ sản ở Hà Nội. Tạp chí Y học thực hành số 482, tháng 7/2004, 16 -19.3.

3. Nguyễn Đức Vy (2012), "Chửa ngoài tử cung", Bài giảng sản phụ khoa, NXB y học, tr. 269-281.

4. Phan Trường Duyệt (2007), " Phẩu thuật ở vòi trứng", Phẫu thuật sản phụ khoa, NXB y học, tr. 363-384.

5. Võ Doã̃n Mỹ Thạnh (2010), "Tình hình phẫu thai ngoài tử cung tại Bệnh viện Nhân Dân Gia Đinh từ 01/2009 đến 04/ 2010" Y hoc Thành Phố Hồ Chí Minh. Tập 14. Phụ bản của số 4. 2010. Tr. 43-48.

6. Phạm Mỹ Hoài (2013), "Đánh giá kết quả phẫu thuật nội soi bệnh lý chứa ngoài tử cung tai Bênh viên Trường Đại học Y Dược Thái Nguyên", Tạp chí Khoa học và Công nghệ tr.177-183.

7. Vũ Văn Du (2011), "Phẩu thuât nội soi điều trì bảo tồn vòi tử cung trong chữa ngoài tử cung bằng phẫu thuâtt nội soi", Luận án tiến sỹ y học, Đai học y Hà Nội.

8. Hà Dưy Tiến, Pham Thanh Hiên(2013), "Đăc điểm lâm sàng và̀ môt số yếu tố liên quan đến chửa ngoài tử cung tại Bệnh viện Phụ Sản Trung ương 2010"Luận án chuyển khoà II, Đ̇ại học Y Hà Nội, Tạp chí nghiên cứu Y học

9. Mark Pearlman, Judith E.Tintinalli, Palmela L. Dyne (2003). Ectopic pregnancy. Obstetric \& Gynecologic emergencies: diagnosis and management: $217-225$.

\title{
ĐÁNH GIÁ TÌNH TRANG SẮT VÀ FERRITIN HUYẾT THANH Ở BỆNH NHÂN SUY THÂ̂N MẠN CHƯA ĐIỀU TRI THAY THẾ TẠI BỆNH VIỆN TRUNG ƯƠNG THÁI NGUYÊN
}

\section{TÓM TẮT}

Mục tiêu: Phân tích mối liên quan giữa sắt và ferritin huyết thanh với tình trang thiếu máu trên bệnh nhân suy thận mãn chưa điêu trị thay thế. Đối tương và phương pháp nghiên cứu: Phương pháp nghiên cứu mô tả cắt ngang tiến hành trên 46 bệnh nhân được chẩn đoán suy thân man giai đoan III, IV chưa điều trị thay thế (chưa lọc máu chu kỳ), điều trị nọi trú tai khoa Thân - Tiết niêu - Bênh viện Trung ương Thái Nguyên. Kết quả và kết İuận: Nồng độ sắt trung bình là $12,41 \pm 12,04 \mu \mathrm{mol} / \mathrm{l}$. Tỷ lệ bệnh nhân có nồng độ sắt huyết thanh giảm là $32,6 \%$. Không có sư khác biệt về nồng độ sắt huyết thanh giữa nam giới và nữ giới và giữa các độ tuổi. Nồng đồ ferritin trung bình là $461,43 \pm 343,75 \mathrm{ng} / \mathrm{ml}$. Có $26,1 \%$ bênh nhân có dự trữ sắt thấp (nồng độ ferritin < 200 $\mathrm{ng} / \mathrm{ml}), 32,6 \%$ bệnh nhân có dự trữ sắt trung bình (nồng đô ferritin từ 200-500 $\mathrm{ng} / \mathrm{ml}$ ) và $41,3 \%$ bênh nhân có tăng dự trữ sắt (nồng độ ferritin $\geq 500 \mathrm{ng} / \mathrm{ml}$ ).

*Trường đại học Y Dược Thái Nguyên Chịu trách nhiệm chính: Nguyễn Thị Ngọc Hà Email: hanguyengoc75@gmail.com Ngày nhân bài: 22.01.2021

Ngày phản biên khoa họ: 18.3 .2021

Ngày duyệt bài: 29.3.2021
Nguyễn Thị Hải Yến*, Nguyễn Thị Ngọc Hà*, Lâm Thị Thu Hương*, Nguyễn Thu Hà*

Nồng độ ferritin huyết thanh có sự khác biệt giữa nam giới và nữ giới (nam lớn hơn nữ). Không có mối tương quan giữa nồng độ sắt và ferritin huyết thanh $p>0,05$. Không thấy mối liển quan giữa nông độ sắt và ferritin huyết thanh với các mức độ thiếu máu.

Tư khóa: Suy thận mạn, sắt, ferritin huyết thanh

\section{SUMMARY}

EVALUATION OF IRON AND FERRITIN

PLASMA STATUS IN CHRONIC KIDNEY

DISEASE PATIENTS WITHOUT

SUBSTANCING TREATMENT IN

THAI NGUYEN GENERAL HOSPITAL

Objective: To analyze the relationship of serum iron and ferritin to anemia status in patients with untreated chronic renal failure. Objects and research methods: Descriptive research methods, the study was conducted on 46 patients diagnosed with stage III and IV chronic kidney failure without replacement treatment, inpatient treatment at the Department of Kidney - Urology - Thai Nguyen General Hospital. Results and conclusions: Average iron concentration is $12.41 \pm 12.04,0 \mu \mathrm{mol} / \mathrm{L}$. The proportion of patients with reduced serum iron concentrations was $32.6 \%$. There is no difference in serum iron levels between men and women and between ages. The mean ferritin concentration was 
$461.43 \pm 343.75 \mathrm{ng} / \mathrm{ml}$. There were $26.1 \%$ of patients with low iron reserves (ferritin concentration $<200$ $\mathrm{ng} / \mathrm{ml}), 32.6 \%$ patients with medium iron reserve (ferritin concentration from $200-500 \mathrm{ng} / \mathrm{ml}$ ) and 41 , $3 \%$ of patients have increased iron reserves (ferritin concentration $\geq 500 \mathrm{ng} / \mathrm{ml}$ ). There are differences in serum ferritin levels between men and women (men are greater than women). There is no correlation between serum ferritin and iron concentrations $p>$ 0.05 . No relationship was found between serum iron and ferritin levels with anemia levels.

Keywords: Chronic kidney disease, iron serum, ferritin serum.

\section{I. ĐĂT VẤN ĐỀ}

Thiễu máu là một trong các biến chứng thường gặp ở người bệnh suy thận mạn. Khi suy thận càng nặng thì tình trạng thiếu máu càng trầm trọng do thận giảm sản xuất Erythropoietin. Đây là chất cần thiết trong quá trình biệt hoá hồng cầu tại tuỷ xương. Đồng thời, khi suy thận mạn bệnh nhân có thế có tình trạng thiếu sắt do nhiều nguyên nhân khác nhau như giảm hấp thu sắt ở đường tiêu hóa, tăng sử dụng sắt, mất máu (do xuất huyết, lây máu xét nghiệm...), viêm nhiếm mạn tính. Điều trị thiếu máu ở bệnh nhân suy thận mạn bằng erythropoietin kết hợp bổ sung sắt có thể mang lại kết quả tôi ưu trong điều trị thiếu máu nhưng cũng có thể gây ra tình trạng quá tải sắt [8]. Vì thế bệnh nhân cần được kiểm tra và theo dõi tình trạng dự trữ sắt một cách chặt chẽ để có phác đồ điều trị thích hợp.

Hiện nay các xét nghiệm để đánh giá tình trạng sắt đã được Hội Thận học Hoa Kỳ khuyến cáo sử dụng trong đánh giá tình trạng dự trữ sắt ở bệnh nhân suy thận mạn giai đoạn cuối điều trị EPO và kết hợp bổ sung sắt là xét nghiệm ferritin huyết thanh và độ bão hòa transferrin, $[6,7]$. Tuy nhiên, xét nghiệm độ bão hòa transferrin còn chưa được áp dụng thường xuyên tại nhiêu khoa xét nghiệm. Trên thế giới và Việt Nam đã có nhiều nghiên cứu về tình trang thiếu máu trên bệnh nhân suy thận mạn kểt hợp bổ sung sắt thông qua xét nghiệm ferritin huyết thanh nhưng chủ yếu tập trung vào đối tượng bệnh nhân STM đã chạy thận nhân tạo chu kỳ.

Trên cơ sở đó chúng tôi tiễn hành đề tài: Đánh giá tình trạng dự trữ sắt thông qua xét nghiệm sắt và ferritin huyễt thanh ở bệnh nhân suy thận mạn chưa điều trị thay thế tại Bệnh viện Trung ương Thái Nguyên với mục tiêu:

1. Xác định nồng độ sắt và ferritin huyết thanh ở bệnh nhân suy thận mạn chưa điêu trị thay thế tại bệnh viện Trung ương Thái Nguyên.
2. Phân tích môi liên quan giữa săt và ferritin huyêt thanh với tình trạng thiếu máu trên bệnh nhân suy thận mãn chưa điều trị thay thế.

II. ĐỐI TƯợNG VÀ PHƯƠNG PHÁP NGHIÊN CỨU

1. Đối tượng nghiên cứu. 46 bệnh nhân suy thân mạn (STM) chưa được điêuu trị thay thế tại Bệnh viện Trung ương Thái Nguyên năm 2020.

\subsection{Tiêu chuẩn chơn bệnh nhân}

Bênh nhân được chẩn đoán bênh thân mạn tính (BTMT) chưa lọc máu chu kỳ, điều trị nội trú tại khoa Thận -Tiết niệu, Bệnh viện Trung ương Thái Nguyên từ tháng 1 năm 2020 đến tháng 11 năm 2020

1.2. Tiêu chuẩn loại trư. Loại trừ khỏi nghiên cứu những bệnh nhân STM đã điều trị EPO, các chế phẩm của sắt hoặc đã được truyền máu trong vòng 3 tháng trước đó, bệnh nhân thận nhân tạo chu kỳ, lọc màng bụng hoặc ghép thận, bệnh nhân bị bệnh máu kèm theo (đa u tuý xương, leukemia cấp, suy tủy xương, thiếu máu tan máu), bệnh nhân bị nhiễm virus: HIV, viêm gan virus $B, C$, bệnh nhân đang có viêm nhiễm cấp tính, suy tim nặng, BN có thai, BN nghiện rượu.

\section{Phương pháp nghiên cứu}

- Phương pháp nghiên cứu: mô tả cắt ngang.

- Cõ mẫu: 46 bệnh nhân vào viện Trung ương Thái Nguyên được chẩn đoán suy thận mạn chưa điêuu trị các biện pháp thay thế năm 2020.

- Phương pháp thu thập sỗ liệu: Thu thập các chỉ tiêu qua hồ sơ bệnh án mẫu

- Chỉ tiêu nghiên cứu:

+ Hành chính: tuổi, giới,

+ Xét nghiệm: CTM (SLHC, Hb, MCV, MCH. $\mathrm{MHCH})$, sinh hóa: Ferritin huyết thanh, sắt huyết thanh, creatinine huyêt thanh

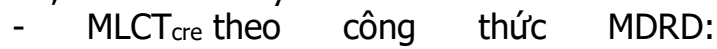
$\operatorname{MLCT}_{\text {cre }}\left(\mathrm{ml} /\right.$ phút $\left./ 1,73 \mathrm{~m}^{2}\right)=186 \times$ (nồng độ creatinin/88,4)-1,154 x (tuổi)-0,203, phân loại giai đoạn suy thận.

- Đánh giá nồng độ ferritin huyết thanh theo Tổ chức chống thiếu máu thế giới:

+ Xác định mối liên quan giữa sắt và ferritin huyết thanh

+ Xác định mối liên quan giữa sắt, ferritin huyết thanh với với tình trạng thiếu máu trên bệnh nhân suy thận.

3. Xử lý số liệu: sử dụng các phân mềm thống kê y học

\section{KẾT QUẢ NGHIÊN CỨU}

1. Mức độ thiếu máu của nhóm bệnh nhân nghiên cứu

Bảng 1: Phân bố mức độ thiêú máu 


\begin{tabular}{|c|c|c|}
\hline Mức độ thiếu máu & $\mathbf{n}$ & $\begin{array}{l}\text { Tỷ lệ } \\
\text { (\%) }\end{array}$ \\
\hline $\begin{array}{c}\text { Thiếu máu } \\
\text { nhẹ }(100 \leq \mathrm{Hb}<120 \mathrm{~g} / \mathrm{l})\end{array}$ & 10 & 21,7 \\
\hline $\begin{array}{c}\text { Thiếu máu } \\
\text { vừa }(70 \leq \mathrm{Hb}<100 \mathrm{~g} / \mathrm{l})\end{array}$ & 26 & 56,6 \\
\hline $\begin{array}{c}\text { Thiếu máu } \\
\text { nặng }(\mathrm{Hb}<70 \mathrm{~g} / \mathrm{l})\end{array}$ & 10 & 21,7 \\
\hline Tống số & 46 & 100,0 \\
\hline
\end{tabular}

Nhân xét: Phần lớn bệnh nhân thiếu máu mức độ vừa $26 / 56$ trường hợp $(56,6 \%)$, thiếu máu nặng chiếm $21,7 \%$.

2. Xét nghiệm sắt và ferritin huyết thanh tuổi và giới

Bảng 2: Giá trị xét nồng độ sắt và ferritin huyêt thanh theo tuôii, giới

\begin{tabular}{|c|c|c|c|c|}
\hline & \multicolumn{2}{|c|}{ Sắt $(\mu \mathrm{mol} / \mathrm{l})$} & \multicolumn{2}{|c|}{ Ferritin $(\mathrm{ng} / \mathrm{ml})$} \\
\hline Nam & $\begin{array}{c}12,44 \pm \\
7,85\end{array}$ & \multirow{3}{*}{$\begin{array}{c}p> \\
0,05\end{array}$} & $\begin{array}{c}578,54 \pm \\
361,04\end{array}$ & \multirow{3}{*}{$\begin{array}{r}\mathrm{p}<0 \\
05\end{array}$} \\
\hline Nũ & $\begin{array}{c}12,37 \pm \\
15,32\end{array}$ & & $\begin{array}{c}344,33 \pm \\
287,53\end{array}$ & \\
\hline Tổng & $\begin{array}{c}12,41 \pm \\
12,04\end{array}$ & & $\begin{array}{c}461,43 \pm \\
343,75\end{array}$ & \\
\hline $\begin{array}{l}<50 \\
\text { tuổi }\end{array}$ & $\begin{array}{c}9,37 \pm \\
2,52\end{array}$ & \multirow{2}{*}{$\begin{array}{c}p> \\
0,05\end{array}$} & $\begin{array}{c}386,53 \pm \\
273,85\end{array}$ & \multirow{2}{*}{$\begin{array}{r}p>0 \\
05\end{array}$} \\
\hline $\begin{array}{l}\geq 50 \\
\text { tuổi }\end{array}$ & $\begin{array}{c}13,14 \pm \\
13,29\end{array}$ & & $\begin{array}{c}479,65 \pm \\
359,57\end{array}$ & \\
\hline
\end{tabular}

Nhân xét: Có sự khác biêtt về nồng độ

Ferritin giữa nam và nữ $(p<0,05)$.

Không có sự khác biệt về nồng độ sắt và

ferritin giữa nhóm tuổi $\geq 50$ và $<50$ tuổi $(p>0,05)$

3. Phân loại nồng độ sắt và ferritin huyết thanh:

Bảng 3: Phân loai giá trị nồng độ sắt và ferritin huyêt thanh

\begin{tabular}{|c|c|c|c|} 
Sắt & $\begin{array}{c}\text { Thấp } \\
>6,6\end{array}$ & $\begin{array}{c}\text { Bình } \\
\text { thường }\end{array}$ & $\begin{array}{c}\text { Cao } \\
>28\end{array}$ \\
\hline
\end{tabular}

5. Liên quan giữa nồng độ sắt huyết thanh với tình trạng thiếu máu Bảng 5: Liên quan giữa sắt và các chỉ số huyêt học (dòng hồng cầu)

\begin{tabular}{|c|c|c|c|c|c|c|c|}
\hline \multicolumn{2}{|c|}{} & RBC & HGB & MCV & MCH & MCHC & HCT \\
\hline Fe & $\mathrm{r}$ & $-0,171$ & 0,096 & 0,200 & 0,368 & 0,315 & $-0,25$ \\
\cline { 2 - 8 }$((\boldsymbol{\mu m o l} / \mathbf{L})$ & $\mathrm{p}$ & 0,255 & 0,527 & 0,159 & 0,008 & 0,024 & 0,871 \\
\hline
\end{tabular}

Nhận xét: Không thấy có mối liên quan giữa sắt với RBC, Hemoglobin, MCV và HCT, có mối liên quan thuận mức độ trung bình giữa sắt và $\mathrm{MCH}, \mathrm{MCHC}$
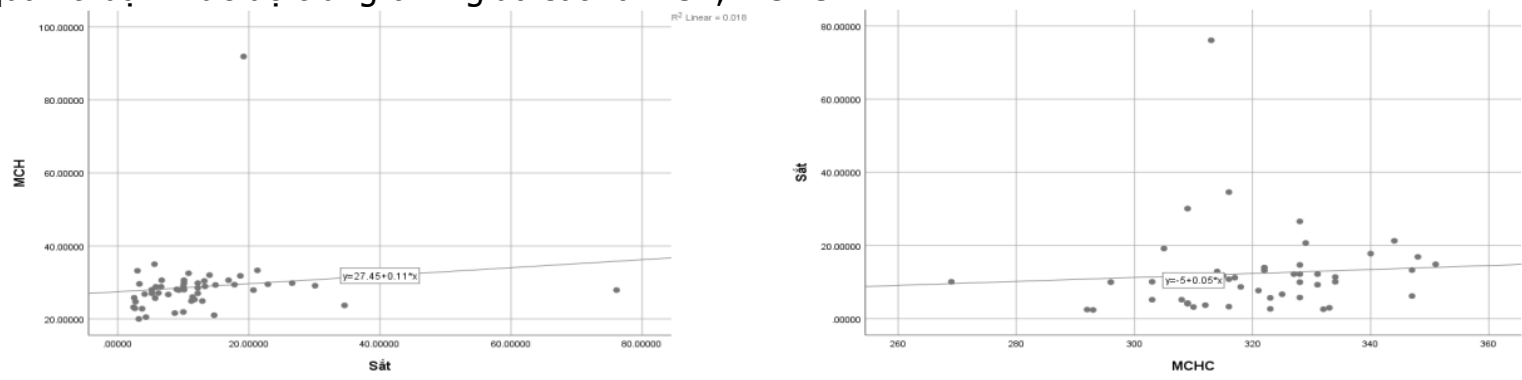

Biểu đồ 2: Đồ thị tương quan giữa Fe và MCHC 
6. Liên quan giữa nồng độ ferritin huyết thanh với tình trạng thiếu máu

Bảng 6: Liên quan giữa ferritin và các chi số huyêt học

\begin{tabular}{|c|c|c|c|c|c|c|}
\hline \multicolumn{2}{|c|}{ Chí số } & RBC & HGB & MCV & MCH & MCHC \\
\hline Ferritin & $\mathrm{r}$ & $-0,115$ & $-0,047$ & 0,072 & 0,251 & 0,225 \\
\cline { 2 - 7 }$(\boldsymbol{\mu} \mathrm{mol} / \mathrm{L})$ & $\mathrm{p}$ & 0,255 & 0,527 & 0,159 & 0,008 & 0,024 \\
\hline
\end{tabular}

Nhận xét: Không thấy có mối liên quan giữa sắt với RBC, Hemoglobin và MCV, có mối liên quan thuận mức độ yếu giữa sắt và $\mathrm{MCH}, \mathrm{MCHC}$.

7. Liên quan giữa nồng độ sắt và ferritin huyết thanh với mức độ thiếu máu

Bảng 7: Liên quan giữa sắt, ferritin huyêt thanh với các mức độ thiếu máu

\begin{tabular}{|c|c|c|c|c|}
\hline Chỉ số & Thiếu máu nhẹ & Thiếu máu vừa & Thiếu máu nặng & $\mathbf{p}$ \\
\hline Fe ( $\boldsymbol{\mu m o l} / \mathbf{L})$ & $10,50 \pm 2,83$ & $11,70 \pm 8,74$ & $16,14 \pm 21,99$ & $>0,05$ \\
\hline Ferritin $(\mathbf{n g} / \mathbf{m l})$ & $439,18 \pm 238,22$ & $502,89 \pm 398,59$ & $375,88 \pm 281,23$ & $>0,05$ \\
\hline
\end{tabular}

Nhận xét: Chưa thấy sự khác biệt có ý nghĩa thống kê giữa sắt và ferritin với các tình trạng thiếu máu trên bệnh nhân suy thận.

\section{BÀN LUẬN}

Bệnh nhân suy thận mạn đặc biệt là ở giai đoạn cuối đều bị thiểu máu. Đây cũ̃ng là một trong những yếu tố khiến tình trạng bệnh trở nên nghiêm trọng hơn. Thiếu máu trong suy thận mạn thường là thiếu máu giảm sinh hồng câuu do thiếu erythropoietin (EPO) nguyên phát hoặc giảm đáp ứng với nó. Ngoài ra, thiếu máu còn do mất máu trong chạy thận nhân tạo, ăn uống kém thiếu chất dinh dưỡng, tăng tốc độ phá hủy hồng cầu hay mất máu mạn tính rỉ rả qua đường tiêu hóa, tình trạng viêm nhiễm.... Thiếu máu mạn tính có thể ảnh hưởng đến chức năng tim, gây giãn mạch, phì đại thất trái [7]. Một số nghiên cứu đã cho thấy rõ tình trạng thiếu máu càng nặng thì nguy cơ nhập viện và tử vong càng cao [trích 7]. Kết quả nghiên cứu của chúng tôi bảng 1 cho thây phần lớn bệnh nhân thiếu máu mức độ vừa và nặng $(56,6 \%$ và $21,7 \%)$. Kết quả này của chúng tổi thấp hơn kết quả của Nguyễn Thị An Thủy (2019) và một số tác giả khác, có lẽ do đối tượng nghiên cứu của chúng tôi lấy từ suy thận giai đoạn sớm hơn (giai đoạn III) và chưa có lọc máu chu kỳ [1], [2], [3].

Chiến lược điều trị thiếu máu trong bệnh thận mạn đã có từ nhiều thế kỷ nay nhưng vẫn còn nhiều vấn đề còn chưa rõ ràng, việc điều trị bổ sung sắt còn đang có nhiều ý kiến. Các nghiên cứu trên thế giới về điều trị thiếu máu ở bệnh nhân suy thận mạn, cũng như khuyến cáo của Hội Thận học Hoa Kỳ chúng tôi ít thấy có khảo sát về sắt và bàn luận về nồng độ sắt huyết thanh. Điều này có thể được lý giải trên cơ sở sinh lý chuyển hóa sắt trong cơ thể, sắt tự do chỉ tồn tại khoảng 2 giờ sau khi tách khỏi transferrin nển giá trị sắt khác nhau ở các thời điểm lấy máu khác nhau [3]. Đồng thời, tình trạng thiếu sắt trong thiếu máu do suy thận mạn thường là thiếu sắt chức năng hơn là thiếu sắt tuyệt đối. Hơn nữa, sắt huyết thanh không cho biết tình trạng dự trữ sắt và lượng sắt được vận chuyển trong huyết tương cũng như lượng sắt có trong tủy xương tạo máu. Trong nghiên cứu của chúng tôi, nồng độ sắt huyết thanh trung bình là $(12,41 \pm 12,04 \mu \mathrm{mol} / \mathrm{L})$ (bảng 2). Kết quả này của chúng tôi thấp hơn kết quả nghiên cứu của Nguyễn Thị An Thủy (2019) có thể số mẫu của chúng tôi còn hạn chế [3]. Tuy nhiên, kết quả nồng độ sắt trung bình của chúng tôi lại cao hơn kết quả của Phan Thễ Cường (2006), có lẽ do đối tượng nghiên cứu của Phan Thế Cường đã có lọc máu chu kỳ, nên có thể bị mất máu làm giảm lượng sắt huyết thanh [1]. Như vậy, hầu hết bệnh nhân trong nhóm nghiên cứu của chúng tôi có nồng độ sắt huyết thanh bình thường. Trong 46 bệnh nhân nghiên cứu, chỉ có $15 / 46(32,6 \%)$ có sắt nồng độ thấp, $60,9 \%$ sắt nồng độ bình thường, và nồng độ cao chỉ $6,5 \%$ (bảng 3). Không thấy sự khác biệt về nồng độ sắt huyết thanh ở nam và nữ và giữa 2 nhóm tuổi $<50$ và $\geq 50$ tuổi $(p>0,05)$. Vì vậy, việc điều trị bổ sung sắt cho bệnh nhân suy thận mạn tính là một vấn đề cần được xem xét. Kết quả thiếu sắt huyết thanh trong nghiên cứu của chúng tôi lại cao hơn nghiên cứu của Nguyễn Thi An Thủy (nồng độ sắt thấp là 17,5\%), nhưng lại thấp hơn kết của của Lê Việt Thắng (nồng độ sắt thấp là $41,86 \%$ ), có thể do số mẫu nghiên cứu của chúng tôi còn khiêm tốn, và đối tượng lựa chọn là không giống nhau [2], [3]

Thiếu máu trong suy thận mạn, đặc biệt thiếu máu nặng mạn tính làm sẽ làm tăng nguy cơ biến chứng tim mạch và tử vong [7]. Tuy nhiên, với sự ra đời của EPO là một cuộc cách mạng trong điều trị thiếu máu suy thận mạn trong hai thập kỷ qua, cùng với chiến lược đánh giá tình trạng sắt để cung cấp bổ sung sắt trong điêu trị, Hội Thận học Hoa Kỳ đưa ra Guideline 
K/DOQI năm 2006 hướng dẫn điều trị thiếu máu trong suy thận mạn [6]: bệnh nhân được bổ sung sắt khi xét nghiệm nồng độ ferritin huyết thanh nhỏ hơn $200 \mathrm{ng} / \mathrm{ml}$. Thiếu sắt chức năng khi ferritin huyết thanh $\geq 200 \mathrm{ng} / \mathrm{ml}$ và đô bão hòa transferrin < $20 \%$. Nguy cơ thừa sắt khi ferritin huyết thanh $\geq 500 \mathrm{ng} / \mathrm{ml}$. Kết quả nghiên cứu của chúng tôi (bảng 2) cho thấy nồng độ ferritin huyết thanh trung bình là $461,43 \pm 343,75 \mathrm{ng} / \mathrm{ml}$. Kết quả này thấp hơn kết quả của Nguyễn Thị An Thủy 583,08 $\pm 375,8$ $\mathrm{ng} / \mathrm{ml}$ và Hoàng Trung Vinh là $538,73 \pm 423,07$ $\mathrm{ng} / \mathrm{ml}$ [3],[4]. Trong đó $26,1 \%$ số bệnh nhân có nồng độ ferritin huyết thanh thấp dưới 200 $\mathrm{ng} / \mathrm{ml}, 32,6 \%$ số $\mathrm{BN}$ có nồng độ ferritin huyết thanh ở mức trung bình và $41,3 \%$ có nồng độ ferritin cao trên $500 \mathrm{ng} / \mathrm{ml}$ (bảng 3). Kết quả này tương tự với nghiên cứu của tác giả Hoàng Trung Vinh thấy có $22,1 \%$ có giảm nồng độ ferritin huyết thanh, tỷ lệ nồng đô ferritin bình thường là $33,6 \%$. So với kết quả sắt huyết thanh của chúng tôi thì ferritin huyết thanh có tỷ lệ cao chiếm phần lớn $(41,3 \%)$, ngược lại sắt huyết thanh nồng độ cao chỉ có $6,5 \%$ (bảng 3 ). Có sự khác biêt nồng độ ferritin huyết thanh trung bình giữa hai giới: nam giới cao hơn nữ giới, giá trị trung bình nam giới là $578,54 \pm 361,04 \mathrm{ng} / \mathrm{ml}$ còn ở nữ giới là $344,33 \pm 287,53 \mathrm{ng} / \mathrm{ml}, \mathrm{p}<0,05$ (bảng 2). Kết quả này của chúng tôi cũng phù hợp với kết quả của Nguyễn Thị An Thủy, Manu Venkatesan [3],[8].Tuy nhiên, không có sự khác biêt nồng độ ferritin huyết thanh trung bình giữa các nhóm tuổi (bảng 2). Ferritin huyết thanh là xét nghiệm đánh giá gián tiếp lượng sắt dự trữ và chiếm khoảng $1 / 8$ lượng sắt dự trữ trong hệ liên võng nôi mô. Đối tượng nghiên cứu của chúng tôi toàn bộ bênh nhân chưa lọc máu và chưa có điều trị thay thế, chính vì vậy xét nghiệm ferritin huyết thanh phần lớn nồng độ cao là rất phù hợp và có giá tri đánh giá tình trang sắt dự trữ hơn với xét nghiệm sắt huyết thanh (chỉ có 6,5\% nồng độ cao). Không thây có mối liên quan giữa nồng độ sắt huyết thanh và ferritin huyết thanh bảng 4 ( $p>0,05)$. Do vậy, việc định lượng nồng độ ferritin huyết thanh ở bệnh nhân suy thận mạn là cần thiết để có chế độ điều trị phù hợp.

- Về mối liên quan giữa sắt, ferritin huyết thanh với tình trạng thiếu máu: Theo kết quả nghiên cứu (bảng 7) chúng tôi nhận thấy nồng độ sắt và ferritin huyết thanh không có mối tương quan với mức độ thiếu máu ở bệnh nhân suy thân man chưa điều trị thay thế. Nghiên cứu của chúng tôi tương tự nghiên cứu của Nguyễn
Văn Thanh cũng cho thấy nồng độ sắt và ferritin huyết thanh không có mối liên quan với mức độ thiếu máu ở bệnh nhân bị suy thận mạn chưa điều trị thay thế [trích 3]. Điêuu này càng khẳng đinh cơ chế bệnh sinh gây thiếu máu của suy thận mạn liên quan đến giảm nồng độ $E P O$ nội sinh và hoặc một số yếu tố khác như giảm đời sông $\mathrm{HC}$ do môi trường ure huyết cao...Tuy nhiên, qua kết quả (bảng 5) cũng cho thấy nồng độ sắt huyết thanh có mối tương quan thuận mức độ trung bình với $\mathrm{MCH}$ và $\mathrm{MCHC}$ với $r=$ 0,$368 ; \mathrm{r}=0,315, \mathrm{p}<0,05$. Kết quả bảng 6 cho thây nồng độ ferritin huyết thanh có mối tương quan thuận mức độ thấp với $\mathrm{MCH}$ và $\mathrm{MCHC}$ với $\mathrm{r}$ $=0,251 ; r=0,225, p<0,05$. Kết quả này của chúng tối cũng phù hợp với các tác giả nghiên cứu trước đây, có nghĩa là khi sắt trong máu tăng thì nồng độ huyết sắc tố trung bình hồng cầu cũng tăng $[1,2,3,4,6,7]$. Chứng tỏ sắt có vai trò quan trong trong quá trình tạo hồng cầu. Khi sắt trong máu đủ đáp ứng cho quá trình này thì nồng độ huyết sắc tố trong giới hạn bình thường. Như vậy, để điều trị thiếu máu trong suy thận mạn tránh những biến chứng nặng nề có thể xảy ra, người thây thuốc cần chú ý, ngoài việc điều trị bằng bổ sung EPO là chất cần thiết kích thích tủy xương sản sinh hồng cầu thì việc bổ sung sắt cũng là vấn đề rất quan trọng cung cấp nguyên liệu tổng hợp hemglobin. Nhưng vấn đề bổ sung sắt khi nào thì cần có xét nghiệm đánh giá tình trạng dự trữ sắt, sắt huyết thanh, đặc biêt là ferritin để có phác đồ điều trị thích hợp tránh quá tải sắt gây tình trạng nguy hiểm cho bệnh nhân.

\section{KẾT LUÂ̂N}

- Nồng độ sắt trung bình là $12,41 \pm$ $12,04 \mu \mathrm{mol} / \mathrm{l}$. Tỷ lệ bệnh nhân có nồng độ sắt huyết thanh giảm là $32,6 \%$. Không có sự khác biệt về nồng độ sắt huyết thanh giữa nam giới và nữ giới và giữa các độ tuổi.

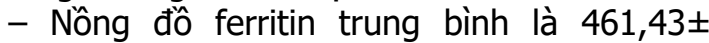
$343,75 \mathrm{ng} / \mathrm{ml}$. Có $26,1 \%$ bệnh nhân có dự trữ sắt thấp (nồng độ ferritin < $200 \mathrm{ng} / \mathrm{ml}$ ), 32,6\% bệnh nhân có dự trữ sắt trung bình (nồng độ ferritin từ $200-500 \mathrm{ng} / \mathrm{ml}$ ) và $41,3 \%$ bênh nhân có tăng dự trữ sắt (nồng độ ferritin $\geq 500$ $\mathrm{ng} / \mathrm{ml}$ ). Nồng độ ferritin huyết thanh có sự khác biệt giữa nam giới và nữ giới (nam lớn hơn nữ).

- Không có mối tương quan giữa nồng độ sắt và ferritin huyết thanh $p>0,05$.

- Không thấy mối liên quan giữa nồng độ sắt và ferritin huyết thanh với các mức độ thiếu máu.

\section{TÀI LIỆU THAM KHẢO}


1. Phan Thế Cường, Hoàng Trung Vinh, Nguyễn Anh Trí (2012). Khảo sát tình trạng sắt ở bệnh nhân suy thận mạn giai đoạn cuối trước điêuu trị lọc máu chu kỳ. Tap chí y - dược hoc quân sư, 8, 61-68.

2. Lê Việt Thắng (2011), Nghiên cứu sự thay đổi nồng độ sắt, ferritin huyết thanh bệnh nhân suy thân mạn tính loc máu chu kỳ.Tap chí y học thực hành, 5, 160-162.

3. Nguyến Thi An Thủy, Đỗ Gia Tuyển, Đăng Thi Việt Hà (2018), Đánh giá tình trang dư trữ sắt ơ bệnh nhân suy thận mạn chưa điều trị thay thế qua nồng độ sắt và Ferritin huyết thanh, Tạp chí Nội khoa Việt Nam - số 16.

4. Hoàng Trung Vinh, Phan Thế Cường, Nguyễn Anh Trí (2012). Nghiên cứu biến đổi tình trang sắt ở bệnh nhân suy thân mạn giai đoạn cuối điều tri erythropoietin. Tap chí y hoc thức hành, 9, 24-29.

5. Aleix Casesa, M. Isabel Egocheagab, Salvador Tranchec, et al, (2018) Anemia of chronic kidney disease: 'Protocol of study, management and referral to Nephrology. Nefrología, Vol 38. Issue.1. p1-108

6. KDOQI(2006). Clinicalpractice guidelines and clinical practice recommendations for anemia in chronic kidney disease in adults. Am J Kidney Dis, $47,11-145$.

7. Lucia Del Vecchio, Francesco-Locatelli (2014), Anemia in chronic kidney disease patients: Treatment recommendations and emerging therapies. Expert Review of Hematology 7(4):495-506

8. Manu Venkatesan, Shilpi Saxena, ${ }^{1}$ and Arun Kumar (2019) Evaluation of Iron Status in Patients of Chronic Kidney Disease - A Study to Assess the Best Indicators Including Serum Transferrin Receptor Assay, Indian J Nephrol. 2019 Jul-Aug; 29(4): 248-253.

9. Shaheen F.A., Souqiyyeh M.Z., Al-Attar B.A., et al. (2011). Prevalence of anemia in predialysis chronic kidney disease patients. Saudi J Kidney Dis Transpl, 22(3), 456-463.

\section{NHẬN XÉT GIÁ TRI MộT SỐ YẾU TỐ TRONG TIÊN LƯỢNG SUY GAN CẤP Ở TRẺ EM}

\section{TÓM TẮT}

Suy gan cấp (SGC) là môt hội chứng hiếm gặp đặc trưng bởi tổn thương chức năng gan nhanh và trầm trọng ở bênh nhân trước đó không có tổn thương gan. SGC do nhiều căn nguyên gây ra. Trẻ mắc SGC cần được chẩn đoán phát sớm nguyên nhân và tiên lương được tình trang nă̆ng để có hướng xử trí đúng nhằm hạn chế biến chứng, tử vong. Nghiên cứu mô tả tiến hành trên 94 trẻ SGC với đô tuổi trung bình là 10 tháng, trẻ nhỏ tuổi nhất là 2 ngày, trẻ lớn tuổi nhất là 14 tuổi. Nhóm tuổi có tỷ lẹ cao nhất là trẻ nhũ nhi chiếm $44,7 \%(n=43)$, tiếp theo là trẻ nhỏ $43,6 \%$ $(n=42)$. Tré lớn $(\geq 12$ tuối) và trẻ sơ sinh có tỷ lê thấp $7,4 \%(n=7)$ và $4,3 \%(n=4)$. Không có sự khác biệt về giới tính về tỷ lế mắc bênh. Nguyên nhẩn $\mathrm{SGC}$ thường gặp nhất là bệnh chuyển hóa $(23,4 \%)$ với bệnh Wilson, rối loạn chuyển hóa chu trình ure, thiếu hụt citrin là những bệnh chính. Tỷ lệ SGC không rõ nguyên nhân chiếm $47,9 \%$. Các triêu chứng vàng da, bệnh não gan và gan teo nhỏ là các triệu chứng thường găp ở các bệnh nhân có tiên lượng xâu. Xét nghiệm cận lâm sàng có giá trị tiên lượng tử vong là INR cao nhất trên 4,2 với AUC $=0,74$, độ nhay $72,1 \%$, độ đặc hiệu $74,5 \%$, giá trị dự báo dương tính $68,9 \%$, giá trị dự báo âm tính $75,5 \%$ và Bilirubin $\geq 300 \mu \mathrm{mol} / \mathrm{l}$ cho giá trị tiên lượng ở mức độ trung bình với $A U C \geq 0,7$.

*Bệnh viện Nhi Trung ương

Chiu trách nhiệm chính: Nguyễn Pham Anh Hoa

Email: Dranhhoa@nch.org.vn

Ngày nhân bài: 25.01.2021

Ngày phản biên khoa họ: 23.3.2021

Ngày duyệt bài: 29.3.2021
Nguyễn Phạm Anh Hoa*, Mai Thị Giang* lượng

Tư khóa: Suy gan cấp, INR, Bilirubin, yễu tỗ tiên

\section{SUMMARY}

VALUE OF SOME PREDICTIVE FACTORS IN PROGNOSIS PEDIATRIC HEPATIC FAILURE

Acute liver failure (ALF) is a rare syndrome characterized by rapid deterioration of normal liver function following an acute insult in a patient with no previously known underlying chronic liver disease. AHF in children is caused by many causes. Children with SGC need to be diagnosed the cause and prognosis in order to have the manage to minimize complications and death. Descriptive study was conducted on 94 AHF children. The average age of patients is 10 months (2 days- 14 years old). The highest age group was infants, accounting for $44.7 \%$ $(n=43)$, followed by children with $43.6 \%(n=42)$. Older children ( $\geq 12$ years) and infants had a low rate of $7.4 \%(n=7)$ and $4.3 \%(n=4)$. There is no gender difference in incidence. The most common causes of AHF are metabolic diseases (23.4\%). In which, Wilson disease, urea cycle metabolic disorder, and citrin deficiency are the main diseases. The group of unknown etiology AHF is $47.9 \%$. Jaundice, hepatic encephalopathy and hepatic atrophy are common symptoms in patients with a poor prognosis. INR $>4.2$ is the highest predictive test with with AUC $=0.74$, sensitivity $72.1 \%$, specificity $74.5 \%$, positive predictive value $68,9 \%$, a negative predictive value of $75.5 \%$. Bilirubin value $\geq 300 \mu \mathrm{mol} / \mathrm{l}$ is a moderate prognostic value with $A \cup C \geq 0.7$. Keywords: Acute hepatic impairment, INR, Bilirubin, prognostic factors.

I. ĐẶT VẤN ĐỀ 